\title{
Chemical Polymorphism of the Essential Oils from Populations of Thymus caespititius Grown on the Islands Pico, Faial and Graciosa (Azores)
}

\author{
S. I. Pereira, ${ }^{1}$ P. A. G. Santos, ${ }^{1}$ J. G. Barroso, ${ }^{1 *}$ A. C. Figueiredo, ${ }^{1}$ L. G. Pedro, ${ }^{1}$ L. R. Salgueiro, ${ }^{2}$ \\ S. G. Deans ${ }^{3}$ and J. J. C. Scheffer ${ }^{4}$ \\ ${ }^{1}$ Centro de Biotecnologia Vegetal, Departamento de Biologia Vegetal, Faculdade de Ciências de Lisboa, Bloco C2, Campo Grande, 1749-016 \\ Lisbon, Portugal \\ ${ }^{2}$ Laboratório de Farmacognosia, Faculdade de Farmácia, Universidade de Coimbra, Rua do Norte, 3000 Coimbra, Portugal \\ ${ }^{3}$ Department of Pharmaceutical Sciences, University of Strathclyde, Glasgow G4 0NR, Scotland, UK \\ ${ }^{4}$ Division of Pharmacognosy, LACDR, Leiden University, Gorlaeus Laboratories, PO Box 9502, 2300 RA Leiden, The Netherlands
}

\begin{abstract}
The compositions of the essential oils isolated from the aerial parts of 11 populations of Thymus caespititius collected during the flowering phase on Pico, Faial and Graciosa (Azores) were studied by GC and GC-MS. The monoterpene fraction was dominant in all the oils analysed (55-90\%) and consisted mainly of oxygencontaining compounds (44-79\%). Sesquiterpenes represented an important fraction of the oils from the populations grown on Graciosa (13-28\%). In contrast, this fraction was rather small in the oils from the populations grown on Pico and Faial (6-11\%). Despite this, oxygen-containing compounds (4-18\%) were always dominant. Cluster analysis of all identified oil components grouped the oils into three main clusters that corresponded with their main components. The oils from the 11 populations studied showed a clear chemical polymorphism that, in some cases, was more evident among populations growing on the same island than among those from different islands. Copyright $\mathbb{C} 2003$ John Wiley \& Sons, Ltd.
\end{abstract}

Keywords: Essential oils; carvacrol; $\alpha$-terpineol; chemotypes; Thymus caespititius; Azores.

\section{INTRODUCTION}

Thymus caespititius Brot. is an endemic species of the Lamiaceae that is characteristic of the Atlantic wet zones of the north-western Iberian peninsula, and of the Madeiran and Azorean archipelagos. This species is the only representative of the genus in the Azorean archipelago, where it is commonly known as 'erva-úrsula' (Fernandes Costa, 1945; Sjögren, 1984; Salgueiro, 1994; Pena and Cabral, 1997).

Previous studies have shown that the essential oils from populations of $T$. caespititius collected in the Portuguese mainland (Fernandes Costa, 1945, 1975; Salgueiro, 1994; Salgueiro et al., 1997) were chemically different from those obtained from populations grown on the Azorean islands Pico and Faial, (Salgueiro et al., 1997; Pereira et al., 1999). However, the oils from the insular populations did not show noticeable differences with respect to their main components (Salgueiro et al., 1997; Pereira et al., 1999). As a part of our screening programme of the aromatic flora of Macaronesia, we here report on the compositions of the essential oils from 11 populations of $T$. caespititius: four grown on Pico, three on Faial and four on the island Graciosa (Azores), as indicated in Table 1.

\footnotetext{
* Correspondence to: J. G. Barroso Centro de Biotecnologia Vegetal, Departamento de Biologia Vegetal, Faculdade de Ciências de Lisboa, Bloco C2, Campo Grande, 1749-016 Lisbon, Portugal

E-mail: jgbarroso@fc.ul.pt

Contract/grant sponsor: Fundação para a Ciência e Tecnologia

Contract/grant number: Praxis/P/BIA/11054/98
}

\section{EXPERIMENTAL}

Plant material. Samples of the aerial parts of T. caespititius were collected during the full flowering period of the plant (June 1999) from 11 populations growing on the islands Pico, Faial and Graciosa (Azores). A voucher specimen of each population has been deposited in the Herbarium of the Museu, Laboratório e Jardim Botânico de Lisboa (Table 1).

Isolation procedure. The essential oils were isolated from deep-frozen $\left(-20^{\circ} \mathrm{C}\right)$ plant material by distillationextraction for $3 \mathrm{~h}$, using a Likens-Nickerson-type apparatus (Likens and Nickerson, 1964) with $n$-pentane as organic solvent, and by hydrodistillation for $3 \mathrm{~h}$, using a Clevenger-type apparatus (Council of Europe, 1996). The oil samples isolated by hydrodistillation were used to estimate the oil yields whilst those isolated by distillation-extraction were used to determine percentage composition since the chance of artefact formation must be considered smaller when the latter extraction method is used.

Analyses. GC and GC-MS analyses were performed according to Pereira et al. (2000). Chiral GC analyses were performed using an FID instrument, a data handling system and a Cyclosil B (Agilent/J\&W Scientific, Palo Alto, CA, USA) fused-silica column $(30 \mathrm{~m} \times 0.25 \mathrm{~mm}$ i.d.; film thickness $0.25 \mu \mathrm{m})$. The oven temperature was maintained at $105^{\circ} \mathrm{C}$; the injector and detector temperatures were $280^{\circ} \mathrm{C}$ and $290^{\circ} \mathrm{C}$, respectively; the carrier gas was hydrogen at a flow of $42 \mathrm{~cm} / \mathrm{s}$.

Cluster analysis. The percentage composition of the essential oil samples was used to determine the relationship 
Table 1. Sites of collection of the eleven populations of Thymus caespititius studied

\begin{tabular}{|c|c|c|c|c|}
\hline Island & Collection site & Population & $\begin{array}{l}\text { Altitude } \\
\text { (m) }\end{array}$ & $\begin{array}{l}\text { Voucher } \\
\text { number }\end{array}$ \\
\hline \multirow[t]{4}{*}{ Pico } & Fajã & P1 & 500 & LISU:171716 \\
\hline & Pico & P2 & 1200 & LISU:171719 \\
\hline & Testada Nova & P3 & 650 & LISU:171718 \\
\hline & Testada Nova & P4 & 700 & LISU:171721 \\
\hline \multirow[t]{3}{*}{ Faial } & Parque Capelo & F1 & 230 & LISU:171730 \\
\hline & Parque Capelo & F2 & 300 & LISU: 171730 \\
\hline & Pico Gordo & F3 & 700 & LISU:171731 \\
\hline \multirow[t]{4}{*}{ Graciosa } & Vertente da Caldeira & G1 & 250 & LISU:171734 \\
\hline & Serra Branca & $\mathrm{G} 2$ & 350 & LISU:171732 \\
\hline & Carapacho & G3 & 125 & LISU:171733 \\
\hline & $\begin{array}{l}\text { Gruta da Maria } \\
\text { Encantada }\end{array}$ & G4 & 300 & LISU:171735 \\
\hline
\end{tabular}

between the different populations of $T$. caespititius by cluster analysis using the NTSYS software (Rohlf, 1992). Euclidean distance was selected as a measure of similarity, and the unweighted pair-group method with arithmetic average (UPGMA) was used for cluster definition.

\section{RESULTS AND DISCUSSION}

Essential oils isolated from the aerial parts of different populations of $T$. caespititius, collected during the flowering phase, were obtained in yields ranging from 0.2 to $0.8 \%(\mathrm{v} / \mathrm{w})$. Thirty-four to 43 components were identified in the eleven oil samples, amounting to a total percentage of $82-96 \%$, which are listed in Table 2 in order of their elution from a DB-1 column.

All of the oils analysed were dominated by their monoterpene fraction $(55-90 \%)$. In the oils obtained from the populations grown on Pico and Faial, this fraction ranged from 80 to $90 \%$ and 79 to $86 \%$, respectively, whereas in those obtained from the populations grown on Graciosa it amounted to $55-80 \%$. The proportion of sesquiterpenes in the oil samples from Pico and Faial (6-7\% and $8-11 \%$, respectively) was rather small compared with that recorded for the oils from the populations grown on Graciosa (13-28\%).

The populations grown on Pico yielded carvacrol-rich oils $(45-57 \%)$, but they differed in their second main components: thymol and carvacryl acetate in the oil from population $\mathrm{P} 1$ (10 and 9\%, respectively), thymol in that from population $\mathrm{P} 4(12 \%)$, and carvacryl acetate in the oils from the populations P2 and P3 (15 and $17 \%$, respectively). Although the populations P3 and P4 were collected from the same area (Testada Nova), the corresponding oils differed markedly not only in their second main components, the proportions of which varied considerably, but also in the proportion of $\alpha$-terpineol. The sesquiterpene fraction represented only $6-7 \%$ of the total oils, T-cadinol $(2-3 \%)$ being its main component. It is noteworthy that remarkable differences were observed with regard to the amounts of carvacrol, carvacryl acetate and thymol in the oil from population P2 (57, 15 and 2\%, respectively) and that reported for an oil sample isolated from plants collected also during the flowering phase at the same site in 1994, $(36,8$ and $16 \%$, respectively; Salgueiro et al., 1997).
The populations collected on Faial also yielded carvacrol-rich oils (51-54\%); however, $\alpha$-terpineol (12\%) in population $\mathrm{F} 1$, p-cymene $(10 \%)$ in population $\mathrm{F} 2$, and $\alpha$-terpineol, $p$-cymene, and carvacryl acetate $(5 \%$ each) in population F3, were their second main components. The sesquiterpenes attained $8-11 \%$ of the total oils, T-cadinol ( $3-4 \%)$ again being the major component of this fraction. Comparing the results obtained for plant material collected in 1999 (populations F1 and F3) with those recorded for two samples collected during the flowering phase of the plant at the same sites in 1998 (Pereira et al., 1999), no remarkable differences could be seen.

The chemical compositions of the essential oils from the populations collected on Graciosa differed markedly from those found for the populations grown on Pico and Faial. In fact, although the oils from the populations G1 and G2 were dominated by carvacrol (35 and 32\%, respectively), the relative amount of this component was lower than in the oils from the populations grown on the other two islands under study. In addition, $\alpha$-terpineol was the second main component of oils G1 and G2 with a relative amount of 15 and $27 \%$, respectively. Comparatively, the amount of $\alpha$-terpineol in the oils from the populations of Pico and Faial was rather small, ranging from 0.4 to $12 \%$. Moreover, the oils obtained from the populations $\mathrm{G} 3$ and $\mathrm{G} 4$ were dominated by $\alpha$-terpineol (33 and 37\%, respectively), with carvacrol (24\%) and T-cadinol (11\%) as the second main components, respectively. The composition of the oil from the population G4 was quite different from that found for the other populations grown either on Graciosa, Pico or Faial. Taking into account the high levels of $\alpha$-terpineol (37\%) and of the sesquiterpene fraction (28\%), dominated by T-cadinol (11\%), the composition of this oil resembled that reported for populations collected in the Portuguese mainland (Salgueiro et al., 1997).

Cluster analysis of the identified components grouped the oils into three main groups (Fig. 1) corresponding with their main components: carvacrol (populations P1-P4 and F1-F3), carvacrol/ $\alpha$-terpineol (populations G1-G3) and $\alpha$-terpineol/T-cadinol (population G4). The clusters formed by the populations $\mathrm{P} 1-\mathrm{P} 4$ and F1-F3 possessed carvacrol-rich oils, but the oils from the populations $\mathrm{P} 1$ and $\mathrm{P} 4$ may better be characterised as carvacrol/thymol-type oils. Likewise, population G1 is clearly separated from the populations G2 and G3, although all three are grouped in the same cluster (Fig. 1). This can be explained by the smaller relative amount of 
Table 2. Percentage compositions of the essential oils isolated from aerial parts, collected during the flowering phase, of eleven populations of Thymus caespititius grown on Pico, Faial and Graciosa

\begin{tabular}{|c|c|c|c|c|c|c|c|c|c|c|c|c|}
\hline \multirow[b]{3}{*}{ Component } & \multirow{3}{*}{$\begin{array}{l}\text { Retention } \\
\text { index }^{a}\end{array}$} & \multicolumn{11}{|c|}{ Populations ${ }^{b}$} \\
\hline & & \multicolumn{4}{|c|}{ Pico } & \multicolumn{3}{|c|}{ Faial } & \multicolumn{4}{|c|}{ Graciosa } \\
\hline & & $\mathrm{P} 1$ & P2 & P3 & P4 & $\mathrm{F} 1$ & $\mathrm{~F} 2$ & F3 & G1 & G2 & G3 & G4 \\
\hline$\alpha$-Thujene & 924 & 2.7 & 1.9 & 2.0 & 2.1 & 1.5 & 1.9 & 2.0 & 1.5 & 1.5 & 0.6 & 0.3 \\
\hline$\alpha$-Pinene & 930 & 0.8 & 0.6 & 0.7 & 0.6 & 0.7 & 0.6 & 0.7 & 0.5 & 0.5 & 0.3 & 0.1 \\
\hline Camphene & 938 & 0.1 & 0.1 & 0.1 & 0.1 & 0.1 & 0.1 & 0.1 & $t^{c}$ & $\mathrm{t}$ & $\mathrm{t}$ & $\mathrm{t}$ \\
\hline Sabinene & 958 & 0.3 & 0.2 & 0.3 & 0.3 & 0.2 & 0.2 & 0.3 & 0.5 & 0.4 & 0.5 & 1.0 \\
\hline Oct-1-en-3-ol & 961 & & & & & & & & 0.9 & 0.2 & 0.8 & \\
\hline$\beta$-Pinene & 963 & 0.3 & 0.2 & 0.3 & 0.2 & 0.6 & 0.6 & 0.4 & $\mathrm{t}$ & 0.9 & $\mathrm{t}$ & 0.6 \\
\hline Dehydro-1,8-cineole ${ }^{d}$ & 974 & & & 0.1 & $\mathrm{t}$ & 0.1 & $\mathrm{t}$ & 0.1 & 0.1 & 0.1 & 0.1 & \\
\hline$\beta$-Myrcene & 975 & & & 0.5 & & $\mathrm{t}$ & $\mathrm{t}$ & $\mathrm{t}$ & & & & \\
\hline$\alpha$-Phellandrene & 995 & 0.2 & 0.1 & 0.1 & 0.1 & 0.1 & 0.1 & 0.1 & 0.1 & 0.1 & 0.1 & $\mathrm{t}$ \\
\hline$\Delta 3$-Carene & 1000 & 0.1 & 0.1 & 0.1 & 0.1 & 0.1 & 0.1 & 0.1 & 0.1 & $\mathrm{t}$ & $\mathrm{t}$ & $\mathrm{t}$ \\
\hline$\alpha$-Terpinene & 1002 & 0.9 & 0.7 & 0.7 & 1.0 & 0.7 & 0.9 & 0.8 & 1.1 & 1.0 & 0.7 & 0.5 \\
\hline p-Cymene & 1003 & 5.5 & 4.0 & 4.2 & 4.5 & 5.0 & 9.6 & 5.1 & 9.5 & 4.4 & 6.6 & 2.6 \\
\hline$\beta$-Phellandrene & 1005 & 0.2 & 0.2 & 0.2 & 0.2 & 0.2 & 0.2 & 0.2 & 0.2 & 0.2 & 0.1 & 0.1 \\
\hline Limonene & 1009 & 0.4 & 0.2 & 0.4 & 0.3 & 0.4 & 0.4 & 0.4 & 0.6 & 0.9 & 0.7 & 1.1 \\
\hline$\gamma$-Terpinene & 1035 & 2.8 & 2.7 & 2.1 & 2.7 & 2.9 & 3.1 & 3.0 & 8.3 & 6.8 & 4.2 & 4.4 \\
\hline Terpinolene & 1064 & 0.2 & 0.1 & 0.2 & 0.1 & 0.2 & 0.2 & 0.2 & 0.2 & 0.2 & 0.2 & 0.3 \\
\hline cis-Sabinene hydrate & 1066 & & & $\mathrm{t}$ & & & & & & & & \\
\hline Linalool & 1074 & $\mathrm{t}$ & $\mathrm{t}$ & & & & & $\mathrm{t}$ & 0.1 & 0.1 & 0.1 & 0.2 \\
\hline Oct-1-en-3-yl acetate & 1086 & $\mathrm{t}$ & $\mathrm{t}$ & 0.2 & 0.1 & & 0.5 & 0.3 & 0.4 & 0.3 & 0.3 & 0.1 \\
\hline Borneol & 1134 & & $\mathrm{t}$ & 0.1 & $\mathrm{t}$ & & 0.1 & 0.1 & 0.1 & 0.1 & & \\
\hline Terpinen-4-ol & 1148 & 0.8 & 0.8 & 0.8 & 0.8 & 0.9 & 1.0 & 0.7 & 1.1 & 0.8 & 0.9 & 1.2 \\
\hline$\alpha$-Terpineol & 1159 & 4.0 & 2.7 & 0.4 & 4.6 & 11.8 & 6.3 & 5.3 & 15.3 & 27.2 & 32.5 & 36.7 \\
\hline Carvone & 1206 & 0.1 & 0.1 & 0.2 & 0.1 & 0.2 & 0.4 & 0.2 & $\mathrm{t}$ & 0.1 & $\mathrm{t}$ & $\mathrm{t}$ \\
\hline Carvacrol methyl ether & 1224 & & $\mathrm{t}$ & $\mathrm{t}$ & & 1.0 & 0.3 & & 0.4 & 0.2 & & 0.2 \\
\hline Thymol & 1275 & 9.7 & 2.4 & 1.4 & 12.1 & 0.7 & 4.6 & 0.1 & 0.1 & 0.6 & 1.1 & 1.4 \\
\hline Carvacrol & 1286 & 48.1 & 56.8 & 48.5 & 44.9 & 51.1 & 51.3 & 54.0 & 35.0 & 32.0 & 24.3 & 3.3 \\
\hline Thymyl acetate & 1330 & 2.9 & 0.6 & 0.3 & 3.6 & 0.5 & 1.1 & & & 0.2 & 0.2 & 0.2 \\
\hline Carvacryl acetate & 1348 & 9.1 & 15.4 & 17.0 & 1.6 & 3.2 & 3.2 & 4.9 & 4.2 & 1.6 & 2.5 & 0.4 \\
\hline$\alpha$-Copaene & 1375 & & & & & & & & $\mathrm{t}$ & & $\mathrm{t}$ & 0.1 \\
\hline$\beta$-Elemene & 1388 & 0.1 & 0.1 & 0.1 & 0.1 & & $\mathrm{t}$ & 0.1 & $\mathrm{t}$ & & $\mathrm{t}$ & 0.1 \\
\hline$\beta$-Caryophyllene & 1414 & 0.1 & 0.1 & 0.1 & $\mathrm{t}$ & $\mathrm{t}$ & $\mathrm{t}$ & 0.1 & 0.1 & 1.1 & 0.1 & 0.2 \\
\hline$\alpha$-Humulene & 1447 & & & & & & & & 0.1 & & $\mathrm{t}$ & 0.1 \\
\hline allo-Aromadendrene & 1454 & & & & & 0.3 & & & 0.5 & 0.3 & 0.7 & 1.3 \\
\hline Germacrene-D & 1474 & & & & & & $\mathrm{t}$ & $\mathrm{t}$ & 0.1 & $\mathrm{t}$ & $\mathrm{t}$ & $\mathrm{t}$ \\
\hline trans-Dihydroagarofuran & 1489 & 0.8 & 0.6 & 0.9 & 0.7 & 2.0 & 2.2 & 2.7 & 1.7 & 1.0 & 2.0 & 3.4 \\
\hline$\alpha$-Muurolene & 1494 & $\mathrm{t}$ & & 0.1 & $\mathrm{t}$ & & & & 0.4 & 0.3 & 0.3 & 0.3 \\
\hline$\gamma$-Cadinene & 1496 & 0.7 & 0.6 & 1.0 & 0.7 & 1.3 & 0.9 & 1.3 & 1.5 & 2.2 & 2.0 & 3.7 \\
\hline Calamenene & 1505 & 0.1 & 0.1 & 0.1 & 0.1 & 0.2 & 0.1 & 0.2 & 0.2 & 0.2 & 0.2 & 0.3 \\
\hline$\delta$-Cadinene & 1505 & 0.3 & 0.3 & 0.5 & 0.4 & 0.3 & 0.3 & 0.5 & 1.5 & 1.1 & 1.0 & 1.9 \\
\hline Kessane $^{\mathrm{d}}$ & 1517 & 0.3 & 0.3 & 0.3 & 0.3 & 0.9 & 1.1 & 1.0 & 0.8 & 0.4 & 0.9 & 1.3 \\
\hline$\alpha$-Cadinene & 1529 & 0.3 & $\mathrm{t}$ & & & 0.1 & $\mathrm{t}$ & $\mathrm{t}$ & 0.1 & 0.1 & 0.1 & 0.2 \\
\hline Elemol & 1530 & 0.1 & 0.3 & & 0.3 & & & & $\mathrm{t}$ & & $\mathrm{t}$ & 0.2 \\
\hline epi-Cubenol & 1600 & & & & & & & & 0.1 & $\mathrm{t}$ & 0.1 & 0.1 \\
\hline T-Cadinol & 1616 & 2.3 & 2.2 & 3.3 & 2.5 & 4.1 & 3.0 & 4.4 & 4.3 & 6.4 & 7.0 & 11.2 \\
\hline$\delta$-Cadinol & 1618 & & & $\mathrm{t}$ & & & & & 0.2 & 0.1 & & $\mathrm{t}$ \\
\hline$\beta$-Eudesmol & 1620 & 0.2 & 0.3 & & 0.3 & & & & & & $\mathrm{t}$ & 0.2 \\
\hline$\alpha$-Cadinol & 1626 & 0.7 & 0.8 & 0.9 & 1.0 & 0.5 & 0.8 & 0.7 & 1.3 & 1.1 & 1.2 & 3.0 \\
\hline Identified components (\%) & & 95.2 & 95.6 & 88.2 & 86.5 & 91.9 & 95.2 & 90.0 & 93.2 & 94.7 & 92.4 & 82.4 \\
\hline \multicolumn{13}{|l|}{ Grouped components (\%) } \\
\hline Monoterpene hydrocarbons & & 14.5 & 11.1 & 11.9 & 12.3 & 12.7 & 18.0 & 13.4 & 22.6 & 16.9 & 14.0 & 11.0 \\
\hline Oxygen-containing monoterpenes & & 74.7 & 78.8 & 68.8 & 67.7 & 69.5 & 68.3 & 65.3 & 56.4 & 63.0 & 61.7 & 43.7 \\
\hline Sesquiterpene hydrocarbons & & 1.9 & 1.5 & 2.2 & 1.6 & 3.1 & 2.4 & 3.2 & 5.3 & 5.7 & 5.3 & 9.5 \\
\hline Oxygen-containing sesquiterpenes & & 4.1 & 4.2 & 5.1 & 4.8 & 6.6 & 6.0 & 7.8 & 7.6 & 8.6 & 10.3 & 18.1 \\
\hline Others & & & & 0.2 & 0.1 & & 0.5 & 0.3 & 1.3 & 0.5 & 1.1 & 0.1 \\
\hline Oil yield $(\%, v / w)$ & & 0.5 & 0.7 & 0.2 & 0.5 & 0.8 & 0.5 & 0.3 & 0.4 & 0.4 & 0.6 & $n d^{\mathrm{e}}$ \\
\hline
\end{tabular}

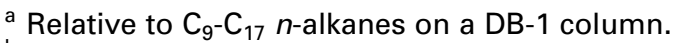

${ }^{b}$ Collection sites as in Table 1.

c $\mathrm{t}=$ trace $(<0.05 \%)$.

$\mathrm{d}$ Identification based on MS only.

e $\mathrm{nd}=$ not determined. 


\section{Euclidean Distance}

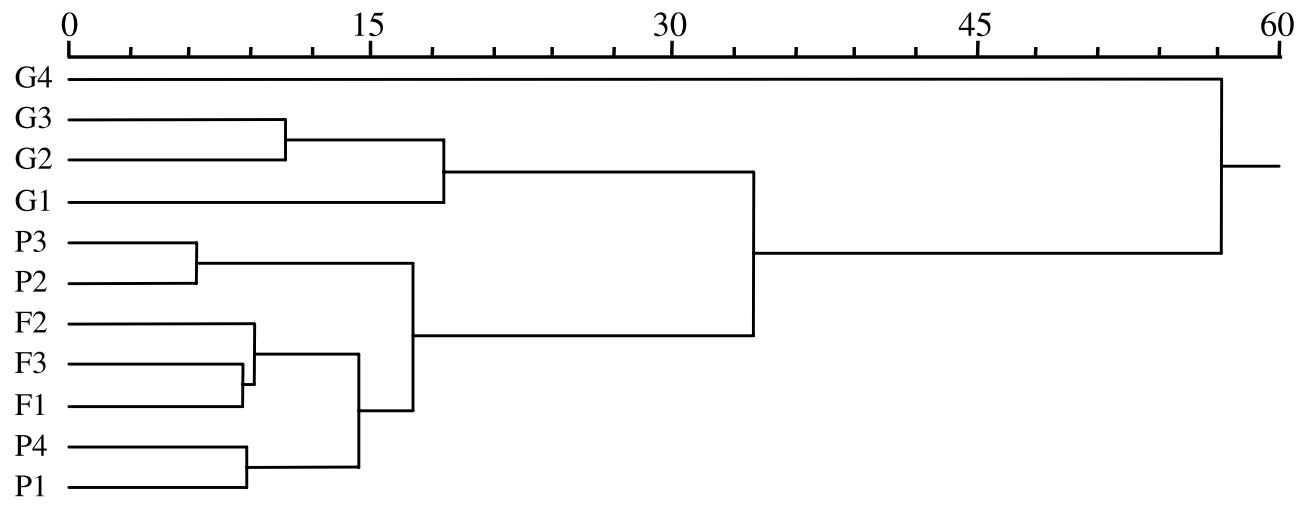

Figure 1. Dendrogram obtained by cluster analysis of the percentage composition of essential oils from 11 populations of Thymus caespititius, based on Euclidean distance and using the unweighted pair-group method with arithmetic average (UPGMA).

Table 3. Enantiomeric percentage composition of $\alpha$-terpineol in the essential oils from populations of Thymus caespititius grown on Pico, Faial and Graciosa

\begin{tabular}{|c|c|c|c|c|c|c|c|c|c|c|}
\hline \multirow[b]{2}{*}{ Component } & \multicolumn{9}{|c|}{ Populations } & \multirow[b]{2}{*}{ G4 } \\
\hline & P1 & $\mathrm{P} 2$ & $\mathrm{P} 4$ & $\mathrm{~F} 1$ & $\mathrm{~F} 2$ & F3 & G1 & $\mathrm{G} 2$ & G3 & \\
\hline (-)- $\alpha$-Terpineol & 3.4 & 3.3 & 3.2 & 3.0 & 3.0 & 3.1 & 2.9 & 11.7 & 14.4 & 25.0 \\
\hline (+)- $\alpha$-Terpineol & 96.6 & 96.7 & 96.8 & 97.0 & 97.0 & 96.9 & 97.1 & 88.3 & 85.6 & 75.0 \\
\hline
\end{tabular}

$\alpha$-terpineol in the oil from population G1 than in those from the other two populations in question.

Of the chiral compounds present in the oils, only $\alpha$ terpineol was investigated with respect to its enantiomeric ratio because of its high concentration in the oil samples from some populations. Although (+)- $\alpha$-terpineol was the predominant enantiomer in all oils analysed (Table 3), its purity showed a considerable variation (75-97\%). In the oils from the populations grown on Pico and Faial and in that from population G1, collected on Graciosa, this compound was detected with a high enantiomeric purity $(97 \%)$, whereas in the oils from the populations G2, G3 and G4 the (+)-enantiomer attained only 88,86 and $75 \%$, respectively (Table 3 ).
Although the populations of $T$. caespititius show a clear chemical polymorphism, no correlation was found between the altitudes of the collection sites (Table 1) and the chemical compositions of the oils. In view of this, the polymorphism recorded in the present study may result either from the genetic variability of the populations or from the influence of edaphic factors.

\section{Acknowledgements}

This study was funded by the Fundação para a Ciência e Tecnologia (FCT), Lisbon, Portugal, under research contract no. Praxis/P/BIA $11054 / 98$.

\section{REFERENCES}

Council of Europe. 1996. European Pharmacopoeia, 3rd edn. Council of Europe: Strasbourg; 121-122.

Fernandes Costa $A$. 1945. Espécies peninsulares do género Thymus L. Bol Esc Farm Univ Coimbra 5: 97-134.

Fernandes Costa A. 1975. Elementos da Flora Aromática. Junta de Investigações Científicas do Ultramar: Lisbon; 118-122.

Likens ST, Nickerson GB. 1964. Detection of certain hop oil constituents in brewing products. Am Soc Brewing Chem Proc 5-13.

Pena A, Cabral J. 1997. Roteiros da Natureza-Região Autónoma dos Açores. Temas e Debates: Lisbon.

Pereira SI, Santos PAG, Barroso JG, Figueiredo AC Pedro LG, Salgueiro LR, Deans SG, Scheffer JJC. 1999. Composição do óleo essencial de duas populações de Thymus caespititius Brot. do Faial. In Ist Congr Plantas Aromáticas Medicinais Países Língua
Oficial Portuguesa, Conimbriga-Ansião, Portugal; 41 (abstract).

Pereira SI, Santos PAG, Barroso JG, Figueiredo AC, Pedro LG Salgueiro LR, Deans SG, Scheffer JJC, 2000. Chemical polymorphism of the essential oils from populations of Thymus caespititius grown on the island S. Jorge (Azores). Phytochemistry 55: 241-246.

Rohlf JF. 1992. NTSYS-pc, Numerical Taxonomy and Multivariate Analysis System. Applied Biostatistics: New York.

Salgueiro LR. 1994. Os Tomilhos Portugueses e os Seus Óleos Essenciais. PhD Thesis. University of Coimbra, Portugal.

Salgueiro LR, Vila R, Tomi F, Figueiredo AC, Barroso JG Cañigueral S, Casanova J, Cunha AP, Adzet T. 1997. Variability of essential oils of Thymus caespititius from Portugal. Phytochemistry 45: 307-311.

Sjögren E. 1984. Accores-Flores. Direcção Regional de Turismo-Horta: Faial. 